\title{
Are the cultural accounting values a relevant issue for the SMEs' financing options?
}

\section{¿Son los valores culturales de la contabilidade una cuestión relevante en las opciones de financiamiento de las pyme?}

\author{
Fabio Albuquerque ${ }^{\mathrm{a}, *}$, Joaquín Texeira Quirós ${ }^{\mathrm{b}}$, Rosário Justino ${ }^{\mathrm{a}}$ \\ a Instituto Politécnico de Lisboa, Portugal \\ b Universidade Autonoma de Lisboa, Portugal
}

Received 9 February 2016; accepted 28 April 2016

Available online 19 November 2016

\begin{abstract}
This paper aims to examine the financing options of the managers/owners of SMEs (small and mediumsized companies) from a point of view that incorporates cultural values, namely, conservatism and secrecy. Data were collected with the use of a questionnaire conducted for managers/owners of a sample of 1629 Portuguese SMEs, and with the use of accounting and financial information from the period 2009 to 2011. 438 managers/owners provided valid answers, corresponding to a response rate of $27 \%$. Using multivariate regression techniques as a basis, the results showed that a significant number of managers/owners supported the negative relationship between conservatism/secrecy and the business financing options associated with a higher risk (debts with costs). The results also showed that a more significant number of managers/owners of national SMEs choose sources of financing in light of the pecking order theory.

(C) 2016 Universidad Nacional Autónoma de México, Facultad de Contaduría y Administración. This is an open access article under the CC BY-NC-ND license (http://creativecommons.org/licenses/by-nc-nd/4.0/).
\end{abstract}

JEL classification: $\mathrm{G} 32$

Keywords: Conservatism; Financing; Secrecy; SMEs

\section{Resumen}

El presente articulo tiene como objetivo examinar las opciones de financiamiento de los administradores y propietarios de las Pymes incorporando en el analisis los valores culturales relacionados con el conser-

\footnotetext{
* Corresponding author.

E-mail address: fabiohfalb@hotmail.com (F. Albuquerque).

Peer Review under the responsibility of Universidad Nacional Autónoma de México.
} 
vadurismo y el secreto. Los datos fueron recogidos mediante un cuestionario realizado a los administradores y propietarios de una muestra de 1,629 pymes lideres en Portugal. Tambien se analizó la información contable y financiera entre los ejercicios 2009 a 2011, habiendo obtenido 438 respuestas, lo que supone un 27\%, que valida la misma. Basado en técnicas de regresión multivariante, los resultados muestran una correlacion negativa entre el conservadurismo y el secreto, analizados en conjunto, y las opciones de financiamiento de las empresas relacionadas con un mayor riesgo, o sea, una financiamiento con costos. También se verifica una correlacion entre la selección de las fuentes de financiamiento de las Pymes a la luz de la teoría de jerarquía de las preferencias de capital.

(C) 2016 Universidad Nacional Autónoma de México, Facultad de Contaduría y Administración. Este es un artículo Open Access bajo la licencia CC BY-NC-ND (http://creativecommons.org/licenses/by-nc-nd/4.0/).

Códigos JEL: G32

Palabras clave: Conservadurismo; Financiación; Pymes; Secreto

\section{Introduction}

Studies related to capital structure theories have mainly used the theoretical contributions that are usually mentioned in the context of corporate finance (Jensen \& Meckling, 1976; Modigliani \& Miller, 1958, 1963; Myers, 1984; Myers \& Majluf, 1984).

Recent theoretical developments have used new variables in order to explain corporate financing, such as the effects of the motivational and cultural factors. Even though there is a large number of existing empirical studies that are based on theories that explain the capital structure of the entities, there is still a small number of studies that explain the motivational factors that underlie the cultural values and the indices of cultural dimensions. These studies aim to explain the capital structure of the companies of the countries under review (Antonczyk \& Salzmann, 2014; Antonczyk, Breuer, \& Salzmann, 2010, 2011; Chui, Lloyd, \& Kwok, 2002; Fairbairn, 2013; Gleason, Mathur, \& Mathur, 2000; Hilgen, 2014; Mac an Bhard \& Lucey, 2014; Poker Junior, Belli, \& Milani Filho, 2015; Rihab \& Lofti, 2011; Wang \& Esqueda, 2014) by using the indices of cultural values of such countries, namely the indices of cultural values proposed by Hofstede (1980) and Schwartz (1994, 1999).

This paper aims to identify the existence of the relationship between two cultural values proposed by the literature on this subject (namely conservatism and secrecy) and the corporate financing options of the managers and/or owners of Portuguese SMEs, based on the Commission Recommendation 2003/361/EC of 6 May 2003. The level of identification with the above mentioned values was determined using a questionnaire. The questions in this questionnaire are related to management and corporate financing and discuss the factors behind the aversion of the SMEs to obtain financing based on the public and private equity. In this sense, conservatism is present when the entity adopts conservative accounting and management practices (e.g. choosing the cost model rather than the fair value model), uses accounting practices that are more in line with the objectives of taxation or is concerned about opening the capital to elements outside the traditional structure of the entity. Secrecy, in turn, is present when the entity strongly resists disclosing information, namely by resorting to less traditional sources of financing which require the entity to disclose more significant information. Unfortunately, said entities (especially the more secretive entities) are not always willing to provide such information.

The model adopted in this study is also in line with the theoretical developments related to the hierarchy of sources of financing mentioned by Myers (1984) in the pecking order theory, 
and mentioned by Barton and Gordon (1987) in their contributions regarding motivational factors such as risk aversion and business strategy. The importance of SMEs in the European economy (which constitute the majority of businesses) and the specific characteristics of the SMEs (which frequently fail to use the same sources of fundraising as the larger companies) help us to create a differentiated analysis of the factors that determine the capital structure (Berger \& Udell, 1998). The European Commission has been recently concerned about the sources of financing available to the SMEs in the context of the financial and economic crisis some countries are currently facing.

Hall, Hutchinson, and Michaelas (2004) concluded in his multi-country study conducted in Europe that both the capital structure of the European companies (SMEs) and the factors that determine it have significant variations that cannot be overlooked. They suggest that there are "differences in attitudes, disclosure requirements, relationships with banks, tax differences and other economic, social and cultural differences" that may be the basis of these differences. For us, "new researches may further explain the country-specific variables that determine the capital structure of the SMEs".

Another factor of interest about this paper is its analysis of debt. It takes into account its more specific characteristic - debt with costs and debt without costs - which is much overlooked in the literature on this subject. This study also differs from the others in that it uses information that was collected not just from the questionnaire or the financial reports of the entities but from both. This way we avoid using indices of cultural values that were already used and developed in other studies (such as Hofstede's [1980] and Schwartz's [1994] indices), and that, despite its subjective factors, may not be able to capture every relevant effect associated with the variable that is intended to be used as an independent variable (Baskerville, 2003).

\section{Theoretical framework}

Studies related to the theories of corporate finance have tried to explain the structure of business financing and the choices made by managers and owners regarding the available sources of financing. These studies include analyses on the optimal capital structure, which take into account the theoretical developments proposed by Modigliani and Miller (1963), which include the theory of immunization, taxation analyses, bankruptcy costs (trade-off), the pecking order theory and agency problems, as well as issues related to signalling and information asymmetries (Berger \& Udell, 1998; Brealey \& Myers, 1998; DeAngelo \& Masulis, 1980; Jensen, 1986; Jensen \& Meckling, 1976; Kim, 1978; Kraus \& Litzenberger, 1973; Leland \& Pyle, 1977; Miller, 1977; Myers, 1977, 1984; Myers \& Majluf, 1984; Ross, 1977; Scott, 1976; Stulz, 1990; Stadler \& Castilho, 1997).

Theories related to immunization, taxation, and bankruptcy costs (Kraus \& Litzenberger, 1973; Modigliani \& Miller, 1963; Ross, 1977; Scott, 1976) focus on the determination of an optimal capital structure through the application of fundamentally rational criteria to the decisions of the economic agents.

The agency costs theory focuses on the complexity of the relationship between the corporate structure and its various actors, namely the managers, owners of capital and creditors. This relationship may lead to conflicts that have an impact on the value of the company, i.e., that may affect the company's investment and financing decisions (Jensen \& Meckling, 1976). It has very different effects depending on the governance structure of the societies. The pecking order theory, initially developed by Myers and Majluf (1984) and later complemented by Myers (1984), fits in this context. It states that the company must choose one type of financing over another, i.e., 
it hierarchizes the available sources of financing. This theory is known for applying other criteria besides strictly rational criteria to the financing decisions that do not arise from the agency problems highlighted by Jensen and Meckling (1976).

Theories based on the effects of information asymmetry are related to the process of possession and provision of information and to the process of quality perception of the provided information from the perspective of the entities that need financing or that finance, and from the perspective of the managers and capital holders who affect the debt maturity (Diamond, 1991; Harris \& Raviv, 1991; Leland \& Pyle, 1977; Ross, 1977).

Other studies have also associated previous contributions with the explanation of capital structure, based on the life cycle of the companies and the different financing needs throughout the different stages (Ang, 1991; Berger \& Udell, 1998; Churchill \& Lewis, 1983; Gibb \& Davies, 1990; Scott \& Bruce, 1987).

Recent theoretical developments have focused on the subjective factors associated with financing options. These factors have been analyzed in the context of behavioural finance and competitive strategies (Ang, 1991; Berger \& Udell, 1998; Churchill \& Lewis, 1983; Gibb \& Davies, 1990; Scott \& Bruce, 1987). These contributions can relate to Barton and Gordon's work (1987), in that subjective and motivational factors are determined from a strategic perspective, and to the pecking order theory initiated by Myers (1984), in that the preferred sources of corporate financing are also taken into account.

Other theoretical developments analyze the influence of the national culture in the determination of the capital structure, the financing options of the companies and the debt maturity (Antonczyk \& Salzmann, 2014; Antonczyk et al., 2010, 2011; Chui et al., 2002; Fairbairn, 2013; Gleason et al., 2000; Hilgen, 2014; Mac an Bhard \& Lucey, 2014; Poker Junior et al., 2015; Rihab $\&$ Lofti, 2011). Furthermore, these studies use variables that are related to the cultural dimensions proposed by Hofstede (1980) and Schwartz $(1992,1994)$. The results of these studies were quite satisfactory. The results showed that researchers must not overlook cognitive factors (such as culture) when explaining the companies' behaviour towards financing decisions. These results also suggest that it is necessary to conduct studies in every country using analyses that go beyond the traditional approach of dividing the countries according to pre-established classifications, e.g. dividing the countries based on the Anglo-Saxon axis (Antonczyk \& Salzmann, 2014; Antonczyk et al., 2010, 2011; Chang, Wee, \& Yi, 2012; Chui et al., 2002; Fairbairn, 2013; Gleason et al., 2000; Hilgen, 2014; Kearney, Mac an Bhaird, \& Lucey, 2012; Mac an Bhaird and Lucey, 2014; Rihab \& Lofti, 2011; Wang \& Esqueda, 2014; Zheng, El Ghoul, Guedhami, \& Kwok, 2012).

These studies highlight the negative relationship between the level of debt and the cultural dimensions associated with risk aversion and/or conservatism, proposed by Hofstede (1980) and Schwartz (1994) respectively. These cultural dimensions were evidenced using, for instance, the results obtained by Mac an Bhaird and Lucey (2014), Chui et al. (2002) and Gleason et al. (2000) regarding total debts, and the results obtained by Kearney et al. (2012), Mac an Bhaird and Lucey (2014) and Zheng et al. (2012) regarding long-term debts. Kearney and Zheng do not agree with the restrictions considered by Chang et al. (2012). In fact, in the context of the relationship between risk aversion and debt, Kearney et al. (2012) emphasize that "SME owners wish to avoid high business risks by reducing the interference from creditors and keeping their autonomy and independence", in which are corroborated by Mac an Bhaird and Lucey (2014) who mention the "SME owners' desire to avoid heightened business risk, and interference from debt providers". Those authors, in particular, have found that the effects of cross-country differences "are generally stronger than firm-characteristic, industry or institutional effects". They also disagree with the results obtained by Chang et al. (2012) seeing as, in the context of SMEs, 
they believe that medium and long term debts pose a higher risk to the owners than short term debts.

In summary, although studies on the inclusion of culture as a factor that explains the social phenomena have received a major boost due to the work carried out by Hofstede (1980), the investigation of this element in the context of corporate finance only started receiving more attention at the beginning of the 21 st century, which is clear from the studies published since then, generally with quite satisfactory results. Taking into account the results achieved, it is expected that the investigation will eventually continue and that it will focus on reviewing the criteria that underlie the inclusion of variables related to cultural dimensions. However, the majority of these studies have adopted a multi-country approach in an attempt to identify cultural differences between various countries, using the scores of cultural values developed by one of the authors mentioned above.

In the context of the literature on the capital structure, the specific characteristics of the SMEs have often been highlighted, along with the difficulties and barriers in accessing finance and any other issues related to information asymmetry. In this context, these are all recurring themes (Ang, Cole, \& Lin, 2000; Bruns \& Fletcher, 2008; Fairbairn, 2013; Hall et al., 2004; Hussain, Millman, \& Matlay, 2006; Jordan, Lowe, \& Taylor, 1998; Lopez-Gracia \& Aybar-Arias, 2000; Mac an Bhaird and Lucey, 2014; Moro, Lucas, Grimm, \& Grassi, 2010; Schmitt, 2002; Sogorb-Mira \& Lopez-Gracia, 2003; Watson \& Wilson, 2002).

\section{Methodology}

This section of the paper presents the dataset that was used and some theoretical arguments that explain why certain variables and hypothesis were used in this study.

Annex 1 provides the questions (Q) of the questionnaire launched, which was used as proxies for the variables presented in this paper.

The hypothesis proposed for this study determined that the level and characteristics of the SMEs' debts were influenced by cultural factors (such as conservatism and secrecy) and by the elements usually mentioned in the theories related to the capital structure.

In addition to identifying the elements that are usually taken into account in the literature on the capital structure, this hypothesis presents the factors that are evidence of a higher or lower level of conservatism or secrecy and associates said factors with the cultural values analyzed in this paper (Baydoun and Willett, 1995; Gray, 1988).

This study analyses data from the period of 2009 to 2011, thus comprising three years of accounting and financial information. The primary data for this paper were collected through indirect observation, i.e., through the analysis of the answers of the questionnaire which was applied to a sample of Portuguese owners and/or managers of SMEs. Studies related to corporate financing usually use this questionnaire as a data collection instrument, along with the accounting data (Antonczyk et al., 2010, 2011; Antonczyk \& Salzmann, 2012, 2014; Hussain et al., 2006; Jordan et al., 1998; Poker Junior et al., 2015).

The selection criteria narrowed down the scope of the study to 1629 national SMEs, from which a total of 438 valid answers were obtained, thus resulting in a final sample that corresponds to a response rate of $27 \%$. The companies were grouped based on their reference sector segments, namely: "Wholesale and Retail Trade"; "Repairs of Motor Vehicles and Motorcycles", "Manufacturing, Mining and Quarrying", "Construction" and "Other Economic Activities". It should also be pointed out that the latter is the most representative one out of the first three. 
The dependent variable used in this study is the debt ratio, which represents a variable that is recurring in literature on culture and the capital structure (Chui et al., 2002; Fairbairn, 2013; Gleason et al., 2000; Hilgen, 2014; Li, Griffin, Yue, \& Zhao, 2011; Rihab \& Lofti, 2011). The distinction of debts based on its cost, i.e., with or without costs, is supported by the literature on the cultural values of conservatism and secrecy and by the theories related to the capital structure, in that incurring debts with costs (such as bankruptcy costs - previously mentioned by Modigliani \& Miller, 1963) leads to a higher business risk. However, despite the existing theoretical support, this variable is usually less empirically tested and, as such, there are very few examples of its application (Jensen \& Uhl, 2008).

Taking into account the bounded and fractional nature of the variable of interest (debt), the regression analysis should be carried out using Papke and Wooldridge's (1996) fractional regression model, which, according to several authors, was specifically developed for modelling proportions (e.g. Bastos \& Ramalho, 2011; Cook, Kieschnick, \& McCullough, 2008; Ramalho \& Silva, 2009). As such, if one chooses to use this variable, one must take into account its theory, which is negatively associated with conservatism/risk aversion due to the increase in future costs and, ceteris paribus, in financial risks (debts with costs create more future risks than debts without costs).

Regarding the proposed independent variables, the explanatory factors that are usually selected from studies on the identification of the corporate financing options in the context of SMEs were taken into account, bearing in mind the studies on the association between corporate financing and cultural values and the indicators that are usually used in studies on the capital structure. In the latter case, relationships identified by the pecking order theory are preferred over relationships identified by theories that rationalize the choices the owners and/or managers make, such as relationships established in the context of the trade-off theory. On the one hand, relationships identified by the pecking order theory are preferred due to the less rational criteria that underlie the hierarchy of sources of financing. On the other hand, they are also preferred due to their association with the cultural values of conservatism/risk aversion (a relationship identified by Barton \& Gordon, 1987).

Thus, based on the framework, this paper determined that the level of conservatism and secrecy is negatively (positively) associated with the level of debt with (without) costs. The factor related to the level of conservatism and secrecy used in this study is based on an index created from the answers of the first question (Q1) of the questionnaire, with high levels for the Cronbach alpha and the Kaiser-Meyer-Olkin measure of sampling adequacy of, respectively, 0.862 and 0.883 . The first question is related to conservatism and secrecy as described in the framework. The studies carried out by Antonczyk et al. (2010, 2011), Antonczyk and Salzmann (2012), Chui et al. (2002), Fairbairn (2013), Gleason et al. (2000), Hilgen (2014), Jensen and Uhl (2008), Poker Junior et al. (2015), Rihab and Lofti (2011), Wang and Esqueda (2013, 2014) and Zheng et al. (2012) found evidences that there is an inverse relationship between risk aversion and/or the level of secrecy and the level of (total or long term) debt.

The level of conservatism and secrecy is determined using the answers of the second and third questions, which are related to financing and to the business management process, respectively. While the first question was more general (determined the level of conservatism and secrecy), the next two questions were related specifically to the importance of certain factors that must be taken into account when obtaining financing (question Q2, with a Cronbach alpha of 0.717), alongside other factors related to business management (question Q3, with a Cronbach alpha of 0.837). Therefore, and since debts with costs are associated with a higher risk of bankruptcy due 
to the costs involved, it is expected that these factors will become associated with a lower level of debt.

In this respect, this paper determined that companies that value and use financial information the most (questions Q4, with a Cronbach alpha of 0.846, and Q5, respectively) have a negative (positive) relationship with the level of debt with (without) costs. According to Baydoun and Willett (1995), conservatism is very important in the analysis of issues related to the quality of the disclosed information, and is associated with physical characteristics such as objectivity, verifiability, reliability, neutrality, and substance over form; secrecy, in turn, is associated with characteristics related to the amount of information disclosed in the financial reports, such as the presentation of aggregated or disaggregated information. Conservatism and secrecy are also related to the analysis of the factors of accountability and to the analysis of the usefulness of the decisions based on financial information (decision usefulness). In this context, conservatism and secrecy are more often associated with the accounting systems of the countries whose accountancy is closely related to taxation and, therefore, have less useful and less important characteristics for decision making purposes. According to Gray (1988), Portugal is one of the countries with the highest levels of conservatism and secrecy.

This paper determined that resorting to public and/or private equities as a financing option (Q6) is negatively (positively) associated with the level of debt with (without) costs. The use of venture capital reduces information asymmetries, and, therefore, it is very easy for the company to reach an optimal capital structure due to a variety of instruments available. In a multi-country study, Antonczyk and Salzmann (2012) used the dependent variable "venture capital" to determine the index of availability of this same variable for each country. They also used independent variables such as cultural indexes of individualism and risk aversion which were proposed by Hofstede (1980). Thus, a more specific question was included that helped identify the companies that consider or have considered the possibility of resorting to the above mentioned sources. This way one may determine if a company has a higher or lower level of conservatism and secrecy (depending on the answer which may be affirmative or negative, respectively) and, consequently, a higher or lower level of debt with costs.

This paper determined that companies where the owners are involved in its management (part), identified in question A1.1, have a negative (positive) relationship with the level of debt with (without) costs. According to Ang et al. (2000), Jensen and Meckling (1976) and Fama and Jensen (1983), agency costs are higher when the number of non-owner managers is higher. On the other hand, professional managers are more concerned about results because their power does not derive from the property itself; as such they adopt more aggressive growth strategies. In the same way as with family businesses, it is suggested that risks associated with owner managers are higher because they are responsible for not losing the company.

This paper also determined that companies mostly owned by non-family members (nfam), identified in question A1.2, have a positive (negative) relationship with the level of debt with (without) costs. According to Ang et al. (2000), companies owned by family members are positively associated with the level of debt, thus meeting the expectations of the agency costs theory. This is due to the fact that it is preferable to have an external debt rather than new partners/shareholders in order to avoid the risk of bankruptcy. High levels of debt, as well as the risk of default, encourage creditors to closely monitor the company (Ang et al., 2000). As such, in the context of SMEs, more risk aversion and confidential attitudes can be expected, namely, due to the fear of bankruptcy or of losing control (e.g. new people taking control). 
Lastly, based on the fiscal number, we were able to include other variables related to the studies on capital structures, which are described below.

1. Maturity (AGE) is negatively associated with the level of debt with (without) costs. The variable "reputation" is generally associated with maturity because the age of the company is usually used as the best proxy for identifying its notoriety. This association was highlighted by Diamond $(1989,1991)$ in the light of the agency costs theory. For creditors, looking at the company's reputation is one way of ensuring that the company will stay in business and meet its commitments, thus eliminating the effects of information asymmetry. For this reason, a positive association between this variable and the level of debt can be expected. On the other hand, according to Berger and Udell (1998), Petersen and Rajan (1994), based on either the pecking order theory or the growth life cycle theory, more mature companies tend to accumulate results, thus resorting to fewer external debts. In a more classical perspective, Myers and Majluf (1984) present the same understanding on this theme. In a latest study, Mac an Bhaird and Lucey (2014) have found precisely this negative association.

2. Non-debt tax shields (NDTS) are negatively (positively) associated with the level of debt with (without) costs. The variable "Non-debt tax shields" is directly related to the theory of taxation and bankruptcy costs initially proposed by Modigliani and Miller (1963) and later developed by DeAngelo and Masulis (1980). According to this theory, tax savings (tax deductibility) that are associated with the cost of the debt are considered beneficial up to the point where the results of the company are able to absorb this effect. Due to excessive debts, companies are more likely to ignore tax shields that do not result exclusively from debts. Thus, DeAngelo and Masulis (1980) suggest that there is a negative association between this variable and debt because, even though there are other tax shields that are not related to debts to choose from, it is preferable to obtain these tax shields through this mechanism than to obtain a higher debt, which, in turn, may lead to bankruptcy. This variable is supported by, and highlighted in, the trade-off theory (Myers, 1984). According to this theory, companies with more non-debt tax shields tend to prefer debts without costs, because they do not need tax shields that result from debts with costs, which are more likely to lead to bankruptcy.

3. The collateral value of assets (COL) is positively associated with the level of debt with (without) costs. Studies on the association between this variable and debt have produced mixed results. While some studies have shown that there is a negative association between this variable and debt (Barton \& Gordon, 1988; Booth, Aivazian, Demirguc-Kunt, \& Maksimovic, 2001), other studies have shown that there is a positive association between this variable and debt (Constand, Osteryoung, \& Nast, 1991; Frank \& Goyal, 2003; Hilgen, 2014; Jordan et al., 1998; Rajan \& Zingales, 1995; Titman \& Wessels, 1988; Wald, 1999). In the context of the effects of taxation on capital structure, DeAngelo and Masulis (1980) relate this variable to non-debt tax shields and, therefore, establish a negative relationship with debt, because the company, by using these assets, avoids the need to resort to debts as a way of obtaining tax shields (i.e., it limits the use of tax shields associated with debts with costs). Conversely, Jensen and Meckling (1976) while taking into account the agency costs theory, claim that using assets as security for liabilities limits the extent to which the managers can use the free cash-flows that are intended for specific projects, which makes companies incur debts and, thus, establish a positive relationship with debt. Myers (1977) suggests that companies that invest more strongly in tangible fixed assets tend to incur debts, because, in case of bankruptcy, it is easier for these assets to maintain their value. This opinion was also supported by Scott (1976). Thus, the authors propose a positive relationship between this variable and the level of debt, seeing as these companies bear even lower bankruptcy costs than companies that invest more heavily in intangible assets (Myers, 1993). This positive 
relationship has also been strengthened in the context of information asymmetries, been mentioned in several studies (Berger \& Udell, 1998) and been supported by the pecking order theory.

4. Growth (GRO) is positively associated with the level of debt with (without) costs. Studies that support the existence of a negative association between growth and debt are based on the possibility of having underinvestment issues that are associated with high growth opportunities and that result in high agency costs. This opinion is also supported by Jensen and Meckling (1976) and Stulz (1990) in the context of the agency costs theory. Although some studies have identified a negative association between growth and debt (Barton \& Gordon, 1988; Kim \& Sorensen, 1986; Rajan \& Zingales, 1995), the positive association established in this study also follows the developments that underlie the pecking order theory proposed by Myers (1984) and Myers and Majluf (1984), in that it states that the company resorts to debts in order to finance its growth (or the investment opportunities), when the ability to generate internal resources (profitability) becomes insufficient. This positive association was empirically validated by Titman and Wessels (1988), Jordan et al. (1998) and Sogorb-Mira and Lopez-Gracia (2003). According to the pecking order theory, the company shall only resort to debts if it cannot be financed through its own resources or if such resources are insufficient to finance its growth.

5. The size of the company (SIZE) is positively associated with the level of debt with (without) costs. There are some studies on the negative association between this variable and debt (Hall et al., 2004; Kim \& Sorensen, 1986; Titman \& Wessels, 1988) but there is a much larger number of studies on its positive association (Berger \& Udell, 1998; Booth et al., 2001; Fama \& French, 2002; Hall et al., 2004; Harris \& Raviv, 1990; Jordan et al., 1998; Myers \& Majluf, 1984; Myers, 1977, 1984; Rajan \& Zingales, 1995; Scott, 1976; Sogorb-Mira \& Lopez-Gracia, 2003). The studies on the positive association between this variable and debt determined that the size of the company is somehow associated with the collateral value of assets: the larger the size, the more guarantees it provides (Scott, 1976). This association was developed in the context of the trade-off theory. In the context of the agency costs theory, Fama and Jensen (1983) argue that companies that are larger and that have a more complex corporate structure and decision-making level have a higher level of information. In turn, Rajan and Zingales (1995) argue that large companies have a lower risk of bankruptcy and are more likely to diversify their sources of financing. In this respect, large companies are less exposed to information asymmetry and, thus, resort to more diverse sources of financing. This diversification, in turn, is associated with the pecking order theory (Myers, 1984).

6. Liquidity (LIQ) is negatively associated with the level of debt with (without) costs. Although there are many studies that use the variable "liquidity" in the analysis of the capital structure of companies, this paper will only focus on the contributions of Antonczyk et al. (2010,2011), Chang et al. (2012), Li et al. (2011) and Sogorb-Mira and Lopez-Gracia (2003). According to the pecking order theory, if a company tends to resort to self-financing, it will also tend to maintain high levels of liquidity in order to avoid resorting to debts (Myers \& Majluf, 1984). This negative association was identified by Sogorb-Mira and Lopez-Gracia (2003) in their study on SMEs in Spain.

7. Profitability (RET) is negatively associated with the level of debt with (without) costs. Theories related to asymmetric information support a positive association between profitability and debt as a way of identifying which projects are profitable and which are not (Leland \& Pyle, 1977; Ross, 1977). Likewise, the trade-off theory supports this positive association, seeing as high levels of results lead to a better use of tax shields. Although some studies have identified a positive association between profitability and debt (Barton \& Gordon, 1988; Frank \& Goyal, 2003), there has been more empirical evidence regarding negative associations in studies on 
capital structure (Booth et al., 2001; Hall et al., 2004; Jensen \& Uhl, 2008; Jordan et al., 1998; Lopez-Gracia \& Aybar-Arias, 2000; Rajan \& Zingales, 1995; Titman \& Wessels, 1988; Wald, 1999; Watson \& Wilson, 2002). However, the negative association proposed in this study is in line with the developments proposed in the pecking order theory by Myers (1984) and Myers and Majluf (1984), in that the most profitable companies avoid resorting to debts more often. Hilgen (2014), as an example of latest study on culture and capital structure, found a negative association between profitability and debt.

8. The risk of the company (RIS) is negatively associated with the level of debt with (without) costs. It is very important to study this variable because it allows us to determine the influence of the risk of the company from the creditors' point of view, (instead of determining the owners and managers' greater or lesser risk-taking), which is the basis for determining the variables associated with conservatism. There is no consensus on which variables should be used as proxy for risk or how they are determined. Such variables are, for example, the standard deviation of the turnover, the profitability of the assets and the use of a coefficient of variation of the turnover (Antonczyk et al., 2010, 2011). Likewise, in literature, there is no consensus on whether the relationship between this variable and debt is positive or negative. While some authors support the existence of positive relationships (Kim \& Sorensen, 1986; Myers, 1977; Toy, Stonehill, Remmers, Wright, \& Beekhuisen, 1974), other authors support the existence of negative relationships (Bradley, Jarrell, \& Kim, 1984; Chung, 1993; Frank \& Goyal, 2003; Leland \& Pyle, 1977).

9. The sector of activity (SEC) is positively (negatively) associated with the level of debt with (without) costs, depending on the specific characteristics of the sectors under consideration. This variable is usually used as a control variable and in association with theories related to the capital structure. There are some examples of its use in the studies proposed by Ang et al. (2000), Antonczyk et al. (2011), Chui et al. (2002), and Lopez-Gracia and Aybar-Arias (2000). In the context of the literature on this subject, the sector of activity helps to explain why some sectors generate high cash flows and, thus, avoid resorting to debts, (Jensen, 1986; Stulz, 1990), and why, in turn, other sectors have higher risks of bankruptcy (e.g. sectors related to technology) and, thus, have greater difficulty in incurring debts (Myers, 1993). Harris and Raviv (1990, 1991) also highlight the influence the sector has in determining the capital structure in specific contexts of analysis, stating that companies in the same industry tend to have similar levels of debt. Likewise, Myers (1984) determined that the nature of the related assets and risks varies depending on the sector of activity.

\section{Analysis of the results}

This section illustrates the application of the models of the determinants of the companies' capital structure decisions to the empirical study.

Table 1 shows the results of the regressions based on the proposed (dependent) debt variables: "debt with costs" and "debt without costs".

The values of the coefficients are identified in Table 1 , as well as the levels of significance related to the relationship between the dependent and independent variables of the proposed models. The model was estimated with a functional form of log-log type and heteroskedastic robust standard errors. The variance inflation factor (VIF) values were used, which allows to identify the level of the variance of an estimated regression coefficient that is increased for the existence of multicollinearity. Those values ranged from 1.063 to 2.351 , with 1.597 as its average. This results expresses the absence of multicollinearity, considering that those figures are lower 
Table 1

Results of the regressions.

\begin{tabular}{|c|c|c|c|c|c|c|c|}
\hline \multicolumn{4}{|c|}{ Debt with costs } & \multicolumn{4}{|c|}{ Debt without costs } \\
\hline Variable & Coeff. & $\mathrm{t}-$ Stat & $p$-Value & Variable & Coeff. & t-Stat & $p$-Value \\
\hline Q1 & -0.007 & -2.46 & 0.014 & Q1 & 0.005 & 2.32 & 0.020 \\
\hline Q2_1 & -0.034 & -1.77 & 0.077 & Q2_1 & 0.018 & 1.19 & 0.235 \\
\hline Q2_2 & -0.015 & -0.70 & 0.486 & $\mathrm{Q} 2 \_2$ & 0.023 & 1.23 & 0.217 \\
\hline Q2_3 & 0.033 & 1.16 & 0.246 & Q2_3 & -0.036 & -1.55 & 0.121 \\
\hline Q2_4 & 0.033 & 1.53 & 0.125 & Q2_4 & -0.013 & -0.65 & 0.514 \\
\hline Q2_5 & -0.001 & -0.04 & 0.965 & Q2_5 & 0.025 & 1.17 & 0.243 \\
\hline Q2_6 & -0.001 & -0.04 & 0.970 & Q2_6 & -0.017 & -0.87 & 0.384 \\
\hline Q3_1 & 0.072 & 1.60 & 0.109 & Q3_1 & -0.010 & -0.26 & 0.792 \\
\hline Q3_2 & -0.072 & -1.73 & 0.084 & Q3_2 & 0.052 & 1.49 & 0.136 \\
\hline Q3_3 & -0.021 & -0.65 & 0.513 & Q3_3 & -0.028 & -1.05 & 0.294 \\
\hline Q3_4 & 0.104 & 2.93 & 0.003 & Q3_4 & 0.028 & 1.09 & 0.275 \\
\hline Q3_5 & -0.022 & -0.58 & 0.563 & Q3_5 & 0.009 & 0.27 & 0.784 \\
\hline Q3_6 & 0.043 & 1.72 & 0.085 & Q3_6 & -0.046 & -2.02 & 0.043 \\
\hline Q4_1 & -0.028 & -0.87 & 0.386 & Q4_1 & -0.006 & -0.23 & 0.816 \\
\hline Q4_2 & 0.000 & -0.01 & 0.992 & Q4_2 & 0.043 & 1.67 & 0.096 \\
\hline Q4_3 & -0.106 & -3.37 & 0.001 & Q4_3 & -0.008 & -0.27 & 0.786 \\
\hline Q4_4 & 0.026 & 0.88 & 0.378 & Q4_4 & -0.038 & -1.46 & 0.144 \\
\hline Q4_5 & 0.041 & 1.59 & 0.112 & Q4_5 & -0.040 & -1.80 & 0.072 \\
\hline Q4_6 & 0.032 & 1.23 & 0.219 & Q4_6 & 0.012 & 0.53 & 0.593 \\
\hline Q5 & 0.007 & 0.25 & 0.806 & Q5 & -0.046 & -1.74 & 0.081 \\
\hline Q6 & 0.004 & 0.08 & 0.939 & Q6 & -0.060 & -1.41 & 0.159 \\
\hline part & 0.060 & 0.87 & 0.386 & part & -0.046 & -0.82 & 0.410 \\
\hline nfam & -0.021 & -0.46 & 0.649 & nfam & 0.053 & 1.32 & 0.186 \\
\hline AGE & -0.005 & -2.56 & 0.011 & AGE & -0.005 & -3.45 & 0.001 \\
\hline NDTS & 0.876 & 1.28 & 0.200 & NDTS & 1.127 & 1.69 & 0.092 \\
\hline $\mathrm{COL}$ & 0.732 & 5.67 & 0.000 & $\mathrm{COL}$ & -0.603 & -5.72 & 0.000 \\
\hline GRO & -0.162 & -1.14 & 0.255 & GRO & 0.278 & 1.98 & 0.047 \\
\hline SIZE & 0.086 & 4.05 & 0.000 & SIZE & -0.079 & -4.41 & 0.000 \\
\hline LIQ & -1.023 & -7.67 & 0.000 & LIQ & -0.193 & -1.59 & 0.113 \\
\hline RET & -0.745 & -2.05 & 0.041 & RET & -0.594 & -1.85 & 0.065 \\
\hline RIS & 0.114 & 0.65 & 0.517 & RIS & -0.005 & -0.05 & 0.964 \\
\hline $\sec 2$ & 0.024 & 0.50 & 0.614 & $\sec 2$ & -0.084 & -2.23 & 0.026 \\
\hline $\sec 3$ & 0.063 & 0.97 & 0.330 & $\sec 3$ & -0.012 & -0.21 & 0.835 \\
\hline $\sec 4$ & 0.048 & 0.90 & 0.367 & $\sec 4$ & 0.018 & 0.29 & 0.770 \\
\hline const & -1.688 & -4.34 & 0.000 & const & 1.513 & 4.65 & 0.000 \\
\hline
\end{tabular}

Source: Created by the authors.

than 10 or even than 5 as suggested by a significant number of authors (e.g. Bayrakdaroğlu1, Ege, \& Yazıc1, 2013; Chechet \& Olayiwola, 2014; Kariuki, 2014; Li \& Harrison, 2008).

The values of the coefficients (coeff.) indicate the directions of the partial effects.

According to the initial estimate of the model, the level of conservatism and secrecy, which is together determined using the answers for the first question, is negatively associated with debts with costs and positively associated with debts without costs. These answers, which are related to both management and corporate financing, can determine the values shown in these tables and the level of conservatism and secrecy of each company.

The level of conservatism and secrecy is also determined using the answers of the second and third questions, which are related to financing and to the business management process, 
respectively. This level is positively (negatively) associated with the level of debt with (without) costs.

However, significant relationships between debt and conservatism/secrecy were not determined from the evaluation of the variable that determines the possibility of resorting to the public and private equity. Likewise, the variables related to the importance and use of financial information are not significantly associated with debt.

The variables related to governance and ownership structures, i.e., the participation of the owners in management offices and in family vs. non-family businesses are not related to debt.

The size and the collateral value of assets are significant in both cases (debt with costs and debt without costs), but have opposite values. Thus, the proposed positive association was only determined in the first case (debt with costs). This can be explained by the higher risk associated with debts with costs, which, from the financiers' (borrowers) point of view, should lead to an increased need for lenders to provide guarantees and information. In this respect, this observation is also in line with the usual claims that the smaller the company, the more difficult it is to obtain bank financing, due to the level of guarantees provided and due to having more information asymmetries, which are the factors that are inversely related to the size of the company.

This explanation is somehow supported by both the trade-off theory and the pecking order theory. Thus, larger companies that have a high collateral value of assets tend to have higher levels of debt with costs (than smaller companies), because smaller companies that have a lower collateral value of assets sometimes don't have access to finance. It should also be noted that there are some studies on capital structure that have already identified the negative relationship between debt and the variables "size" and "collateral value of assets" (Barton \& Gordon, 1988; Booth, Aivazian, Dermirguc-Kunt, \& Maksimovic, 2001; Kim \& Sorensen, 1986; Titman \& Wessels, 1988).

The initial estimate of the model as regards the maturity and profitability were found according to the estimates of the pecking order theory or financial growth life cycle theory, having a negative association with debt (with and without costs). The same evidence was identified by Hilgen (2014) and Mac an Bhaird and Lucey (2014), for instance. Nonetheless, these previous mentioned authors did not separate the types of debts in their analysis. Those results are inverse to the estimates of the agency costs theory and of the trade-off theory, in which maturity and profitability, respectively, are positively associated with debt (with and without costs).

However, no significant associations between growth (which is the basis of the pecking order theory) and debt have been determined (that are in line with the results obtained by Jordan et al. [1998] and Hall et al. [2004], except those regarding debt without costs, in which it is possible to identify a positive association, following the initial estimate).

Likewise, liquidity and non-debt tax shields are only associated with one of the characteristics of the debt that were analyzed in our study: debt with costs and debt without costs, respectively. Liquidity is negatively associated with debts with costs, following the estimates of the pecking order theory. Non-debt tax shields, which is a variable that was defined by the trade-off theory, are positively associated with debts without costs, following the initial estimates. Bradley et al. (1984) are some of the authors who have identified positive relationships between this variable and debt.

However, in both cases, the results of these tables can be explained by the association between debt and conservatism, which determines the lenders' low propensity to risk. Thus, the existence of a negative relationship between liquidity and debt with costs can be explained by the high risks associated with this type of debt, seeing as it is unlikely that a company will resort to debts with 
cost if it has high liquidity. In turn, there is a positive relationship between non-debt tax shields and debt without costs because it is unlikely that a company will resort to debts with costs if it has high risks of bankruptcy. Pettit and Singer (1985) have a different view on this. They claim that non-debt tax shields are not relevant to SMEs, because SMEs usually have low levels of results and, therefore, it is not viable to use such tax shields. However, no association between risk and debt (that is in line with the results obtained by Sogorb-Mira and Lopez-Gracia [2003] in the context of the SMEs in Spain) has been determined.

Finally, the sectors of activity were not significantly associated with debt, conversely to the results obtained by Hall et al. (2004). As an exception was identified a negative relationship between the variable "sec2" ("Manufacturing, mining and quarrying" sector), and debt without costs. In this respect, the effects of the sector as a whole were not sufficient to explain the corporate financing options, conversely to those obtained by Hall et al. (2004).

\section{Conclusions}

According to Chui et al. (2002), there are numerous studies on cultural values, but not many address the problem of culture in the context of corporate financing. In line with this understanding, Chang et al. (2012) state that "in the past, the impact of national culture on financing decisions was largely forgotten; today it is increasingly stressed in investigations". Also Wang and Esqueda (2014) corroborates that "very few studies have tested the theories of corporate financial leverage across countries by accounting for national cultural characteristics. Even when not tested, some recent studies have suggested the inclusion of the culture as an important aspect to be analyzed (e.g. Zerriaa \& Noubbigh, 2015).

The results obtained by Rihab and Lofti (2011) have led us to recommend that studies on debt be carried out in every country. We suggest that cultural and cognitive factors be used in these studies to explain the behaviour of each country towards the corporate financing options. For us, not including social and cultural models in the studies that analyze the factors that determine the capital structure is a major flaw. In turn, the results obtained by Antonczyk et al. (2011) have led us to highlight the importance of including "cultural factors in the financial economy". The same perspective was emphasized by Hilgen (2014) who, using data from European retailers, states that "even after controlling for both firm-specific and country-specific variables, the differences between mean capital structures of the different cultural clusters are significant". Poker Junior et al. (2015), adapting the study developed by Chui et al. (2002), state the conservatism as "the main cultural features to influence the capital structure".

This paper shows that a significant number of managers and owners of Portuguese SMEs support the relationships between the level of conservatism/secrecy and the corporate financing options, in line with the statements that were previously identified in the literature (Chui et al., 2002; Gleason et al., 2000; Hilgen, 2014; Kearney et al., 2012; Mac an Bhaird and Lucey, 2014; Wang \& Esqueda, 2013, 2014; Zheng et al., 2012). This study corroborates these results, in the sense that if a company has high levels of conservatism and secrecy, it will tend to choose corporate financing options that are associated with a lower risk, i.e., that are more conservative (debt without costs).

The results of this questionnaire also show that SMEs that are hierarchized based on the pecking order theory tend to prefer to resort to debts, in line with the more general statements in the literature on this subject (Fairbairn, 2013; Hall et al., 2004; Jensen \& Uhl, 2008; LopezGracia \& Aybar-Arias, 2000; Mac an Bhaird \& Lucey, 2014; Sogorb-Mira \& Lopez-Gracia, 2003; Watson \& Wilson, 2002). 
This study is our contribution to literature on this subject, because it introduces cultural variables that were obtained from a questionnaire and associates them with accounting and finance variables. This association allows us to analyze the capital structure of the SMEs from a point of view that is not widely used in the literature on this subject. Likewise, the analysis of the debt, while taking into account its distinct characteristics (debt with costs and debt without costs), seems to be widely overlooked in the literature, sometimes resulting in inconsistent conclusions that contribute to, according to Myers (1984), the "update of the puzzle" which is associated with the need to understand the capital structure of the companies.

The difficulty in obtaining empirical evidence of association between the proposed variables and debt in the literature on this subject, depending on its characteristics, is probably the basis of the existence of some results that are apparently inconsistent with the literature. Thus, it is expected that the contribution presented in this paper will help to better understand the relationships between corporate financing options, cultural values and the variables that underlie the modern theories of corporate capital structure.

\section{Annex 1. Questionnaire}

Note: All information collected in this questionnaire is strictly confidential. The data will be solely used for statistical purposes. The results extracted from here will be presented in aggregate format.

Please indicate your position in this entity:

(Manager and shareholder / Non-manager and shareholder)

Please indicate your VAT number:

(This information will allow us to get economic and financial information which is not provided in this questionnaire)

Part I: General information on the entity

A1. Please indicate the shareholder structure (in \%) at the end of the year, based on the type of shareholders and corporate relationships:

A1.1 Type of shareholders:

Managers:

Non-managers:

A1.2 Corporate relationships:

Capital is at least $50 \%$ owned by familiar members (Yes / No): 
Part II: Specific information on the management

Q1. Using thescale below, pleaseindicate your opinion for each of the following statements:

1: strongly disagree 5: strongly agree

1.1 The maintaining of confidentiality of enterprise strategic information can be ensured by the stability of the shareholders and boards of management:

1.2 The entry of new shareholders presents the risk of a deviation of the enterprise growth strategy, taking into account the lack of knowledge of the project originally conceived by initial entrepreneurs:

1.3 The funding from current resources of shareholders of the entity presents as the main advantage the concealment of internal information to external entities:

1.4 More important than the return on the resources invested by current shareholders is to maintain the financial stability of the enterprise, so that you can avoid opening the capital of the enterprise to third parties:

1.5 In choosing among the possible sources of financing available to the enterprise, should be rejected the options that determine the disclosure to third parties of strategic information:

1.6 The participation of shareholders in the enterprise management is always beneficial to the extent that these elements represent the key stakeholders in the entity's performance:

1.7 The risk of opening the capital of an enterprise to a third party is directly related to the need to share information to persons or entities other than initial entrepreneurs:

1.8 Financialstability is in generalthe reflection of the stability of the enterprise's shareholders and management:

1.9 The information of strategic nature should be known only to the shareholders and managers, why should be avoided external funding sources which require the disclosure of this information:

1.10 Diversification of sources of corporate financing presents more risks than benefits, especially when it comes to the possible involvement of others in the enterprise management:

1.11 The opening of the capital of an enterprise to a third party, as a possible source of funding, presents as downside the mandatory disclosure of a broader set of information:

1.12 The trust relationship established between the shareholders is critical to the success of the enterprise, being even more important than the individual skills of each shareholder: 
1.13 In choosing among the available funding sources, even more important than the cost of financing is the analysis of the involvement of external persons or entities in the management decisions of the enterprise:

1.14 The continuity of a society must be fundamentally guaranteed by the stability of the shareholders and boards of management:

Q2. Using the scale below, please indicate the degree of importance to the following factors to be considered in the process of financing:

1: less important $\quad$ 5: more important

2.1 The maintenance of the control of the enterprise:

2.2 The benefits and / or tax benefits associated:

2.3 The borrowing costs:

2.4 The disclosure requirements associated:

2.5 The sharing of management decisions:

2.6 The risk diversification:

Q3. Using thesameprevious scale, pleaseindicate the degreeof importanceto the following aspects of business management:

3.1 The image and reputation of the enterprise:

3.2 Strategies that ensure the enterprise going concern:

3.3 The minimization of business risks:

3.4 The definition of politics of financing:

3.5 Strategies that ensure growth:

3.6 The decision making by other members:

Q4. Using the scale below, please indicate the degree of utility that you attribute to the natures of financial information extracted from accounting:

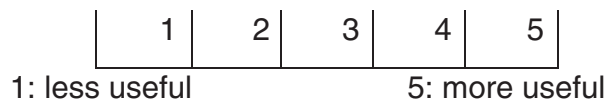


4.1 Information from balance-sheet:

4.2 Information from income statement:

4.3 Other financial information (e.g.: notes):

4.4 Information from statement of changes in equity:

4.5 Information from cash-flow statement:

4.6 Financial information other than financial statements:

Q5. Using the same previous scale, please indicate the degree of utility that you attribute to the accounting information:

Q6. Have you ever considered the possibility of using funding sources based on public or private equity? (Yes/No):

\section{Thank you for your valuable contribution to this research!}

\section{References}

Ang, J. (1991). Small business uniqueness and the theory of financial management. Journal of Small Business Finance, 1(1), 1-13.

Ang, J. S., Cole, R. A., \& Lin, J. W. (2000). Agency costs and ownership structure. The Journal of Finance, 55(1), 81-106. http://dx.doi.org/10.1111/0022-1082.00201

Antonczyk, R., Breuer, W., \& Salzmann, A. (2010). Relationship lending versus arm's length debt-A cultural perspective (October 31, 2010). Working paper. http://dx.doi.org/10.2139/ssrn.1700895

Antonczyk, R., Breuer, W., \& Salzmann, A. (2011). National culture and the choice between bank and bond financing. Working paper.

Antonczyk, R., \& Salzmann, A. (2012). Venture capital and risk perception. Zeitschrift für Betriebswirtschaft, 82(4), 389-416. http://dx.doi.org/10.1007/s11573-012-0556-1

Antonczyk, R., \& Salzmann, A. (2014). Overconfidence and optimism: The effect of national culture on capital structure. Research in International Business and Finance. Working paper. http://dx.doi.org/10.1016/j.ribaf.2013.06.005

Barton, S., \& Gordon, P. (1987). Corporate strategy: Useful perspective for the study of capital structure? Academy of Management Review, 12, 67-75. http://dx.doi.org/10.5465/AMR.1987.4306479

Barton, S., \& Gordon, P. (1988). Corporate strategy and capital structure. Strategic Management Journal, 9, 623-632. http://dx.doi.org/10.1002/smj.4250090608

Baskerville, R. (2003). Hofstede never studied culture. Accounting, Organizations and Society, 28, 1-14. http://dx.doi. org/10.1016/S0361-3682(01)00048-4

Bastos, J., \& Ramalho, J. (2011). Nonparametric models of financial leverage decisions. Working paper. http://dx. doi.org/10.1111/boer.12054

Bayrakdaroğlu1, A., Ege, I., \& Yazıc1, N. (2013). A panel data analysis of capital structure determinants: Empirical results from Turkish capital market. International Journal of Economics and Finance, 4(5), 131-140. http://dx.doi.org/ 10.5539/ijef.v5n4p131

Baydoun, N., \& Willett, R. (1995). Cultural relevance of western accounting systems to developing countries. Abacus, 31, 67-92. http://dx.doi.org/10.1111/j.1467-6281.1995.tb00355.x

Berger, A., \& Udell, G. (1998). The economics of small business finance: The roles of private equity and debt markets in the financial growth cycle. Journal of Banking \& Finance, 22(613), 673. http://dx.doi.org/10.1016/ S0378-4266(98)00038-7

Booth, L., Aivazian, V., Demirguc-Kunt, A., \& Maksimovic, V. (2001). Capital structures in developing countries. Journal of Finance, 56(1), 87-130. http://dx.doi.org/10.1111/0022-1082.00320 
Bradley, M., Jarrell, G. A., \& Kim, E. (1984). On the existence of an optimal capital structure: Theory and evidence. Journal of Finance, 39(3), 857-878. http://dx.doi.org/10.1111/j.1540-6261.1984.tb03680.x

Brealey, R., \& Myers, S. (1998). Princípios de finanças empresariais (5.ed.). Lisboa: McGraw-Hill.

Bruns, V., \& Fletcher, M. (2008). Banks' risk assessment of Swedish SMEs. Venture Capital, 10(2), 171-194. http://dx.doi.org/10.1080/13691060801946089

Chang, K., Wee, J. B., \& Yi, H. C. (2012). Does national culture influence the firm's choice of debt maturity? Asia-Pacific Journal of Financial Studies, 41(4), 424-457. http://dx.doi.org/10.1111/j.2041-6156.2012.01078.x

Chechet, I. L., \& Olayiwola, A. B. (2014). Capital structure and profitability of Nigerian quoted firms: The agency cost theory perspective. American International Journal of Social Science, 1(3), 139-158.

Chui, A. C., Lloyd, A. E., \& Kwok, C. C. (2002). The determination of capital structure: Is national culture a missing piece to the puzzle? Journal of International Business Studies, 33(1), 99-127. http://dx.doi.org/10.1057/palgrave.jibs.8491007

Chung, K. (1993). Asset characteristics and corporate debt policy: An empirical test. Journal of Business and Finance Accounting, 20(1), 83-98. http://dx.doi.org/10.1111/j.1468-5957.1993.tb00251.x

Churchill, N., \& Lewis, V. (1983). The five stages of small business growth. Harvard Business Review, 1-11.

Constand, R. L., Osteryoung, J. S., \& Nast, D. A. (1991). Asset-based financing and the determinants of capital structure in the small firm. In Advances in small business finance. pp. 29-45. Netherlands: Springer. http://dx.doi.org/10.1007/978-94-011-3462-0_3

Cook, D. O., Kieschnick, R., \& McCullough, B. D. (2008). Regression analysis of proportions in finance with self selection. Journal of Empirical Finance, 15, 860-867. http://dx.doi.org/10.1016/j.jempfin.2008.02.001

DeAngelo, H., \& Masulis, R. W. (1980). Optimal capital structure under corporate and personal taxation. Journal of Financial Economics, 8(1), 3-29. http://dx.doi.org/10.1016/0304-405X(80)90019-7

Diamond, D. (1989). Reputation acquisition in capital markets. Journal of Political Economy, 97(4), 828-862.

Diamond, D. (1991). Debt maturity structure and liquidity risk. Quarterly Journal of Economics, 106, 710-737.

Fairbairn, G. (2013). National Culture's Influence on the Capital Structure of SMEs. Thesis: University of Stirling.

Fama, E., \& French, K. (2002). Testing trade-off and pecking order predictions about dividends and debt. Review of Financial Studies, 15, 1-33. http://dx.doi.org/10.1093/rfs/15.1.1

Fama, E., \& Jensen, M. (1983). Agency problems and residual claims. Journal of Law and Economics, 26, 327-350.

Frank, M., \& Goyal, V. (2003). Testing the pecking order theory of capital structure. Journal of Financial Economics, 67, 217-248. http://dx.doi.org/10.1016/S0304-405X(02)00252-0

Gibb, A., \& Davies, L. (1990). In pursuit of frameworks for the development of growth models of the small business. International Small Business Journal, 9(1), 15-31. http://dx.doi.org/10.1177/026624269000900102

Gleason, K. C., Mathur, L. K., \& Mathur, I. (2000). The interrelationship between culture, capital structure, and performance: Evidence from European Retailers. Journal of Business Research, 50(2), 185-191. http://dx.doi.org/ 10.1016/S0148-2963(99)00031-4

Gray, S. (1988). Towards a theory of cultural influence on the development of accounting systems internationally. Abacus, 24, 1-15. http://dx.doi.org/10.1111/j.1467-6281.1988.tb00200.x

Hall, G. C., Hutchinson, P. J., \& Michaelas, N. (2004). Determinants of the capital structures of European SMEs. Journal of Business Finance and Accounting, 31(5-6), 711-728. http://dx.doi.org/10.1111/j.0306-686X.2004.00554.X

Harris, M., \& Raviv, A. (1990). Capital structure and the informational role of debt. The Journal Finance, 45(2), 321-349. http://dx.doi.org/10.1111/j.1540-6261.1990.tb03693.x

Harris, M., \& Raviv, A. (1991). The theory of capital structure. The Journal of Finance, 46, 297-355. http://dx.doi. org/10.1111/j.1540-6261.1991.tb03753.x

Hilgen, M. (2014). The impact of cultural clusters on capital structure decisions: Evidence from European retailers. Working papers.

Hofstede, G. (1980). Culture's consequences: International differences in work-related values. London: Sage Publications.

Hussain, J., Millman, C., \& Matlay, H. (2006). Access to Entrepreneurial Finance: An International Perspective. The International Conference on Financing of SMEs in Developed Countries 4-5th April 2006. University of Warwick.

Jensen, M. (1986). Agency Costs of Free Cash Flow, Corporate Finance and Takeovers. American Economic Review, 76(2), 323-329. http://dx.doi.org/10.2139/ssrn.99580

Jensen, M., \& Meckling, W. (1976). Theory of the firm: Managerial behaviour, agency cost and ownership structure. Journal of Financial Economics, 3, 305-360. http://dx.doi.org/10.1016/0304-405X(76)90026-X

Jensen, N., \& Uhl, F. (2008). Capital structure in European SMEs: An analysis of firm and country specific variables in determining leverage. Working Paper.

Jordan, J., Lowe, J., \& Taylor, P. (1998). Strategy and financial policy in UK small firms. Journal of Business Finance and Accounting, 25(1-2), 1-27. http://dx.doi.org/10.1111/1468-5957.00176 
Kearney, C., Mac an Bhaird, C., \& Lucey, B. (2012). Culture and capital structure in small and medium sized firms. Working Paper. http://dx.doi.org/10.2139/ssrn.2185284

Kariuki, A. (2014). Intellectual capital, corporate reputation, corporate culture and performance of firms listed at the Nairobi securities exchange. PhD Thesis: University of Nairobi.

Kim, E. (1978). A mean-variance theory of optimal capital structure and corporate debt capacity. Journal of Finance, 33 , 45-64. http://dx.doi.org/10.1111/j.1540-6261.1978.tb03388.x

Kim, W., \& Sorensen, E. (1986). Evidence on the impact of the agency costs of debt on corporate debt policy. Journal of Financial and Quantitative Analysis, 21(2), 131-144. http://dx.doi.org/10.2307/2330733

Kraus, A., \& Litzenberger, R. (1973). A state preference model of optimal financial leverage. Journal of Finance, 3(2), 104-110. http://dx.doi.org/10.1111/j.1540-6261.1973.tb01415.x

Leland, H. E., \& Pyle, D. H. (1977). Informational asymmetries, financial structure, and financial intermediation. The Journal of Finance, 32(2), 371-387. http://dx.doi.org/10.1111/j.1540-6261.1977.tb03277.x

Li, K., Griffin, D., Yue, H., \& Zhao, L. (2011). National culture and capital structure decisions: Evidence from foreign joint ventures in China. Journal of International Business Studies, 42, 477-503. http://dx.doi.org/10.1057/jibs.2011.7

Li, J., \& Harrison, J. R. (2008). Corporate governance and national culture: A multi-country study. Corporate Governance International Journal of Business in Society, 8(5), 607-621. http://dx.doi.org/10.1108/14720700810913278

Lopez-Gracia, J., \& Aybar-Arias, C. (2000). An empirical approach to the financial behaviour of small and medium sized enterprises. Small Business Economics, 14(1), 55-63. http://dx.doi.org/10.1023/A:1008139518709

Mac an Bhard, C. an, \& Lucey, B. (2014). Culture's influences: An investigation of inter-country differences in capital structure. Borsa Istanbul Review, 14, 1-9. http://dx.doi.org/10.1016/j.bir.2013.10.004

Miller, M. (1977). Debt and taxes. Journal of Finance, 32, 261-275. http://dx.doi.org/10.1111/j.1540-6261.1977. tb03267.x

Modigliani, F., \& Miller, M. (1958). The cost of capital, corporate finance and the theory of investment. American Economic Review, 48, 261-297.

Modigliani, F., \& Miller, M. H. (1963). Corporate income taxes and the cost of capital: A correction. American Economic Review, 53, 433-443.

Moro, A., Lucas, M., Grimm, U., \& Grassi, E. (2010). Financing SMEs: A model for optimizing the capital structure. In 17th Annual Global Finance Conference.

Myers, S. (1977). Determinants of corporate borrowing. Journal of Financial Economics, 5, 147-175. http://dx.doi.org/ 10.1016/0304-405X(77)90015-0

Myers, S. (1984). The capital structure puzzle. Journal of Finance, 39, 575-592. http://dx.doi.org/10.1111/j.1540-6261. 1984.tb03646.x

Myers, S. (1993). Still searching for optimal capital structure. Journal of Applied Corporate Finance, 1(6), 4-14. http://dx.doi.org/10.1111/j.1745-6622.1993.tb00369.x

Myers, S., \& Majluf, N. (1984). Corporate financing and investment decisions when firms have information that investors do not have. Journal of Financial Economics, 11, 187-221. http://dx.doi.org/10.1016/0304-405X(84)90023-0

Papke, L. E., \& Wooldridge, J. M. (1996). Econometric methods for fractional response variables with an application to 401(K) plan participation rates. Journal of Applied Econometrics, 11, 619-632. http://dx.doi.org/10.3386/t0147

Petersen, M., \& Rajan, R. (1994). The benefits of lending relationships: Evidence from small business data. Journal of Finance, 49(1), 3-37.

Pettit, R., \& Singer, R. (1985). Small business finance: A research agenda. Financial Management, 14, 47-60.

Poker Junior, J. H., Belli, M. M., \& Milani Filho, M. A. F. (2015). The influence of national cultural values in the capital structure of enterprises. Business and Management Review, 4(7), 482-490.

Rajan, R., \& Zingales, L. (1995). What do we know about capital structure? Some evidence from international data. The Journal of Finance., 50(5), 1421-1460. http://dx.doi.org/10.2307/2329322

Ramalho, S., \& Silva, J. (2009). A two-part fractional regression model for the financial leverage decisions of micro, small, medium and large firms. Quantitative Finance, 9(5), 621-636. http://dx.doi.org/10.1080/14697680802448777

Rihab, B., \& Lofti, B. (2011). Socio-cultural heritage and financial decisions: An empirical study. Educational Research, 2(11), 1685-1707.

Ross, S. A. (1977). The determination of financial structure: The incentive signaling approach. Bell Journal of Economics, 8, 23-40. http://dx.doi.org/10.2469/dig.v27.n1.2

Schmitt, D. (2002). Financiamento das pequenas e médias empresas: Aspectos do processo de decisão empresarial e o instrumento de capital de risco. Dissertação de mestrado. Universidade Federal do Rio Grande do Sul.

Schwartz, S. (1992). Universals in the content and structure of values: Theoretical advances and empirical tests in 20 countries. In M. P. Zanna (Ed.), Advances in experimental social psychology (Vol. 25) (pp. 1-65). San Diego, CA: Academic Press. http://dx.doi.org/10.1016/S0065-2601(08)60281-6 
Schwartz, S. (1994). Beyond individualism/collectivism: New dimensions of values. In U. Kim, H. C. Triandis, C. Kagitcibasi, S. C. Choi, \& G. Yoon (Eds.), Individualism and collectivism: Theory application and methods. Newbury Park, CA: Sage.

Schwartz, S. (1999). Cultural value differences: Some implications for work. Applied Psychology: An International Review, 48, 23-47. http://dx.doi.org/10.1111/j.1464-0597.1999.tb00047.x

Scott, J. (1976). A theory of optimal capital structure. Bell Journal of Economics, 7(1), 33-54. http://dx.doi.org/ $10.2307 / 3003189$

Scott, M., \& Bruce, R. (1987). Five stages of growth in small business. Long Range Planning, 20, 45-52. http://dx.doi. org/10.1016/0024-6301(87)90071-9

Sogorb-Mira, F., \& Lopez-Gracia, J. (2003). Pecking order versus trade-off: An empirical approach to the small and medium enterprise capital structure. Working paper. http://dx.doi.org/10.2139/ssrn.393160

Stadler, I., \& Castilho, D. (1997). An introduction to the economic of information. New York: Oxford University Press.

Stulz, R. (1990). Managerial discretion and optimal financing policies. Journal of Financial Economics, 26, 3-27. http://dx.doi.org/10.1016/0304-405X(90)90011-N

Titman, S., \& Wessels, R. (1988). The determinants of capital structure choice. Journal of Finance, 43, 1-19. http:// dx.doi.org/10.2307/2328319

Toy, N., Stonehill, A., Remmers, L., Wright, R., \& Beekhuisen, T. (1974). A comparative international study of growth, profitability, and risk as determinants of corporate debt ratios in the manufacturing sector. Journal of Financial and Quantitative Analysis, 9(5), 875-886. http://dx.doi.org/10.2307/2329684

Wald, J. K. (1999). How firm characteristics affect capital structure: An international comparison. Journal of Finance Response, 22(2), 161-187. http://dx.doi.org/10.1111/j.1475-6803.1999.tb00721.x

Wang, D., \& Esqueda, O. (2013). How national culture and country governance affect firms' leverage decisions and cash holdings: Evidence from Asian ADRs. Working paper.

Wang, D., \& Esqueda, O. (2014). National cultural effects on leverage decisions: Evidence from emerging-market ADRs. Research in International Business and Finance, 31, 152-177. http://dx.doi.org/10.1016/j.ribaf.2013.06.006

Watson, R., \& Wilson, N. (2002). Small and medium size enterprise financing: A note on some of the empirical implications of a pecking order. Journal of Business Finance and Accounting, 29(3/4), 557-578.

Zheng, X., El Ghoul, S., Guedhami, O., \& Kwok, C. C. (2012). National culture and corporate debt maturity. Journal of Banking \& Finance, 36, 468-488. http://dx.doi.org/10.1016/j.jbankfin.2011.08.004

Zerriaa, M., \& Noubbigh, H. (2015). Determinants of capital structure: Evidence from Tunisian listed firms. International Journal of Business and Management, 10(9), 121-135. http://dx.doi.org/10.5539/ijbm.v10n9p121 